\title{
上部尿路カテーテル長期留置患者の腎機能について
}

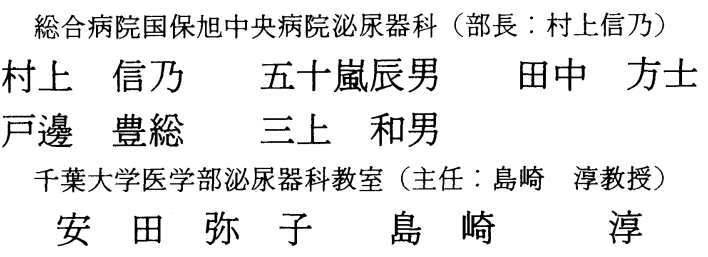

\section{RENAL FUNCTIONS OF THE PATIENTS WITH LONG-TERM CATHETERIZATION IN UPPER URINARY TRACT}

\author{
Shino Murakami, Tatsuo Igarashi, Masashi Tanaka, Toyofusa Tobe and Kazuo Mikami \\ Department of Urology, Asahi General Hospital \\ Mitsuko Yasuda and Jun Shimazaki \\ Department of Urology, Chiba University School of Medicine
}

In order to investigate long-term effects of indwelling urinary catheters on renal functions, in 46 patients (27 male and 19 female) with ureterostomy or nephrostomy serum creatinine values were measured periodically. Average age of the patients was 60.6 years old. Duration of catheterization was more than 3 years (average 8.1 years). Renal dysfunction was defined as an elevation of serum creatinine more than $2 \mathrm{mg} / \mathrm{dl}$. It was found that catheterization used more than 15 years evoked renal insufficiency over $50 \%$ of such patients. This period, however, was shorten to 11 years in patients with nephrolithiasis or frequent fever. It was concluded that urolithiasis and symptomatic urinary tract infections were two remarkable risk factors for the deterioration of renal functions, and that these risk factors must be avoided in patients on long-term catheterization in the upper urinary tract.

Key words: indwelling urinary cathter, renal function

\begin{abstract}
要旨：各種疾患により 3 年以上, 腎瘻や尿管瘦などで上部尿路に直接カテーテルを留置している46名(男 27 , 女 19 , 平均年齢60.6歳, 平均留置期間8.1年)の血清クレアチニン值を指標に腎機能の推移を調べた. カテーテル留置開始後 15 年で, 血清クレアチニン值 $2.0 \mathrm{mg} / \mathrm{dl}$ 以上の腎機能障害が始まる危険性が $50 \%$ を越えた。尿路結石合併例と頻回発熱例ではその数值が11年であったので, 長期カテーテル留置が必要 な患者には, 結石形成と尿路感染症の発症を出来るだけ防ぐ必要があると考えられた。 キーワード：長期留置カテーテル，腎機能
\end{abstract}

\section{緒言}

日常の泌尿器科診療において, 時に様々な原因によ る永久的な尿管の通過障害に対し，尿路変更を必要と する例に遭遇する事がある，尿路変更の方法は種々あ るが, リスクの高い患者に対しては，侵襲の少ない， 尿路に直接カテーテルを留置する腎瘻, あるいは尿管 皮膚瘦が古くより行われて来た。最近は後者ではカ テーテル留置に伴う尿路感染を避ける意味で, 無カ テーテル法が広く行われているが1)21，ストーマ狭窄の ため, カテーテル留置が止むを得ない例も少なくな (3). また長期カテーテル留置は尿路感染以外にも, 結
石形成や腎機能障害などの弊害もあるため, 出来るだ け避けるべきとされているが，その面での詳しいデー ターはまだ報告されていないようである。 今回，この ように上部尿路に, 直接カテーテルを長期間留置した 場合の弊害を知る目的で, 血清クレアチニン值を指標 に，腎機能の推移を調べたので報告する。

\section{対象および方法}

対象は1970年以来, 旭中央病院泌尿器科と千葉大学 付属病院泌尿器科で, 膀胼全摘出術後の尿路変更とし ての尿管皮膚瘦や，尿路結核による尿路狭窄に対する 腎瘻などで， 3 年以上カテーテルを留置している患者 
表 1 対象

\begin{tabular}{|c|c|c|c|c|c|c|c|}
\hline & \multirow[b]{2}{*}{ 例数 } & \multicolumn{3}{|c|}{ 基礎疾患 } & \multirow{2}{*}{$\begin{array}{l}\text { 年齢 } \\
\text { (慼) }\end{array}$} & \multirow{2}{*}{$\begin{array}{c}\text { カテーテル } \\
\text { 留置期間(年) }\end{array}$} & \multirow{2}{*}{$\begin{array}{l}\text { 腎機能不全 } \\
\text { (透析例) }\end{array}$} \\
\hline & & 膀胱腫瘍 & $\begin{array}{l}\text { その他の } \\
\text { 悪性腫瘍 }\end{array}$ & $\begin{array}{c}\text { その他 } \\
(\text { Tbcなど) }\end{array}$ & & & \\
\hline 男 & 27 & 23 & 0 & 4 & $66.4+14.7$ & $6.75+4.4$ & $7(4)$ \\
\hline 女 & 19 & 6 & 4 & 9 & $52.2+20.1$ & $10.0+6.0$ & $5(3)$ \\
\hline 計 & 46 & 29 & 4 & 13 & $60.6+18.4$ & $8.1+5.3$ & $12(7)$ \\
\hline
\end{tabular}

の内, 留置直後の血清クレアチニン值が $2.0 \mathrm{mg} / \mathrm{dl}$ 以 下であった46名（男27，女19）である（表 1)。男性の 尿路変更を必要とした基礎疾患のほとんどは, 膀胱腫 瘍術後の尿路変更であったが, 女性では悪性腫瘍と結 核による上部尿路狭窄が半数ずつであった。長期留置 中に血清クレアチニン值が永続的に $2.0 \mathrm{mg} / \mathrm{dl}$ 以上 の，腎機能不全となっていた患者は12名であり，この 内 7 名は慢性血液透析を受けていた。推計学的に女性 の方が年䶨は若く，カテーテルの留置期間が長い傾向 を認めたが，腎機能不全の発生率は両性間に有意差を 認めなかった。 カテーテルの留置法と各々の留置期間 について表示する(表 2).32名が最初に両側尿管皮膚 瘦を作成されたが, その内の 9 例は長期間留置中に尿 管狭窄を生じ, 腎瘦に変更されている. 従ってこの表 より，両側尿管皮膚瘦術の腎機能不全発生率が低い上 らにも見えるが, 後に腎瘦に変更された例も含めると， カテーテル留置法別の腎機能障害の発生率に差を認め なかった。これら46名のカテーテル留置後からの，各 年度毎の発熱回数と, 結石形成の有無を病歴より調べ ると共に, 血清クレアチニン值を指標に KaplanMeier 法を応用して, 各年度毎の腎機能障害と尿路結 石の発生率を計算した。

\section{結 果}

これら46名の対象の内, 17 名でカテーテル挿入側の 腎に結石を認めた。このような長期留置に伴う結石の 発生率を計算すると, 図 1 のごとく, 約 9 年で $50 \% を$ 越光るが，12年で $67 \%$ に達しそのまま20年迄不変で あった。

血清クレアチニン值が $2.0 \mathrm{mg} / \mathrm{dl}$ 以上の腎機能不全 の状態に達する危険率は, 全体では留置後 5 年で約 $13 \% ， 15$ 年で $50 \%$ を越えていた（図 2 ). これを結石合 併の有無に分けて検討すると，結石合併例では 5 年で $25 \%, 11$ 年で $50 \%$ を越光，17年で $100 \%$ に達したのに対 し, 結石の無い例では15年までは腎機能が正常で, 16 年で $50 \%$ の腎機能が障害される結果であった（図 3 ). Mantel-Haenszel 法により, 推計学的に両群間の有意
表 2 カテーテル留置法

\begin{tabular}{|c|c|c|c|}
\hline & 例数 & $\begin{array}{l}\text { 腎機能不全 } \\
\text { (透析例) }\end{array}$ & 留置期間(年) \\
\hline 両側尿管皮膚瘦 & 23 & $3(1)$ & $4.86+3.38$ \\
\hline $\begin{array}{c}\text { 両側尿管皮席瘻 } \\
\text { 腎 }^{\circledR} \text { 瘻 }\end{array}$ & 9 & $4(2)$ & $10.78+3.90$ \\
\hline 単側尿管皮屚瘻 & 4 & $2(1)$ & $7.75+3.50$ \\
\hline 単側腎瘻 & 10 & $3(3)$ & $10.75+5.90$ \\
\hline 計 & 46 & $12(7)$ & $8.1+5.3$ \\
\hline
\end{tabular}

図 1 結石発生率

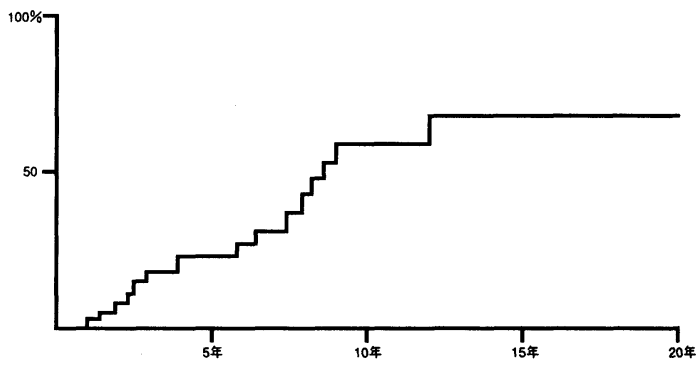

図 2 腎機能障害発生率（全体）

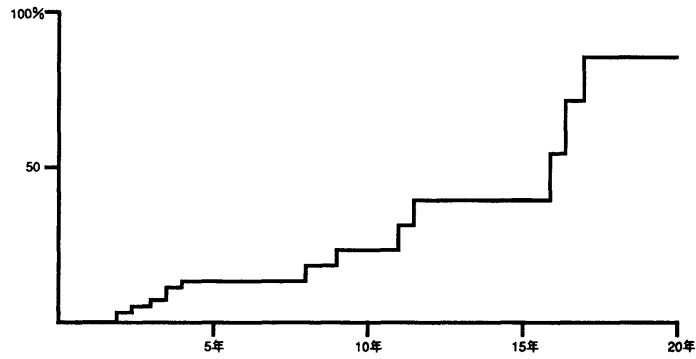

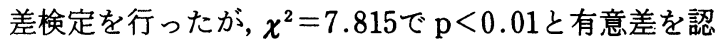
めた。つまり結石を合併する例は，より早く堅機能が 障害される傾向が明らかとなった。

更に症候性尿路感染症の主症状である38度以上の発 熱を, 年 1 回以上認めた頻回発熱群23例と, それ以外 の非発熱群23例に分けて, 同じょ5に各年度毎の腎機 能障害の発生率を計算した(図 4 )。頻回発熱群では11 
図 3 腎機能障害発生率（結石）

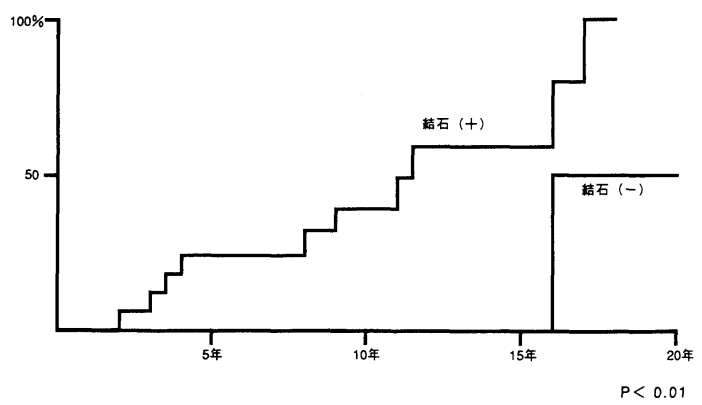

図 4 腎機能障害発生率（発熱）

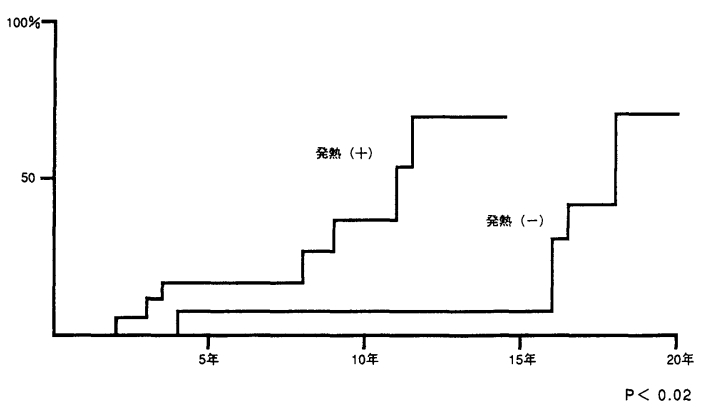

年に対し，非発熱群では 17 年で $50 \%$ の患者の腎機能が

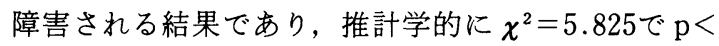
0.02 と有意差を認めた。

\section{考 察}

尿路変更の手段として，腎瘦や尿管皮膚瘻などで, 上部尿路から直接皮虞を通して，尿を外飞誘導する方 法は古くより扣こなわれて来た。その対象となる疾患 は，10年以上前までは自験例での女子の如く，尿路結 核による尿管狭窄も少なくなかったが，最近は膀胖腫 瘍, 子宮癌などの骨盤内悪性腫瘍に対する尿路变更が 大部分となっている，尿路変更の期間は基礎疾患によ り, 癌進行に伴ら尿管狭窄に対する対症療法としての 一時的なものと, 膀胼腫瘍に対する膀胼全摘出術後の 尿路变更のような永久的なものに二分される．何れの 場合も，以前はカテーテルが留置されていたが，最近 は永久的な尿路変更の場合には, 出来るだけカテーテ ルを留置しない努力がなされている，その理由は長期 留置に必発のカテーテル表面での結石形成々，尿路感 染を避けるためである。大川らによれば，留置期間 1 週間で $20 \%$ 以上のカテーテル表面に, 燐酸塩などの結 石成分の付着を認めたと報告されている4). 今回のわ れわれの成績でも，上部尿路への長期留置患者の $50 \%$
に，9年で尿路結石が発生していたので，尿路への異 物であるカテーテルの留置は, 結石形成の弊からも出 来るだけ避けるべきであろう。 またカテーテル留置に 伴ら尿路感染は, 回路の閉鎖性を保つ蓄尿バッグの使 用により減少したとはいっても5), 留置期間が長くな れば必発である677). そしてカテーテル表面に付着した 細菌はbiofilm を形成して抗菌剤を無効にするなど, その治療は困難である ${ }^{819)}$. そのため膀脱全摘後の永久 的な尿路变更法としては，カテーテルを必要としない 回腸導管や Kock pouch などが広く行われている。し かし高齢者などの poor riskの患者に対しては, 手術 侵襲の少ない尿管瘻は捨て難い尿路变更法である。そ こで種々の無カテーテルによる尿管皮膚瘦の術式が試 みられている。しかし一旦無カテーテルに成功しても， 後にストーマの狭窄をきたして, カテーテル留置のや むなきに至る例も少なくない。このようにやむを得ず 長期間, 上部尿路に直接カテーテルを留置した場合に 問題となることは，結石形成や尿路感染により生ずる 腎機能の障害であり, その進展による腎不全患者の発 生である。日本透析療法学会の統計では, 1991年末現 在, 全国の 110,559 人の透析患者の原疾患の内, 慢性腎 孟腎炎, 結石症や閉塞性尿路疾患など, その一部に長 期カテーテル留置が関係すると考兄られる疾患は 2,946名, $2.8 \%$ と少なくない数値が報告されている ${ }^{10)}$. 自験例でも, 3 年以上の長期間, 上部尿路に直接カテー テルが留置されている46人の患者のうち，12名の腎機 能が障害されており, しかも7 名が現在慢性透析療法 を受けていた事実は，腎機能障害が長期留置での最も 重大な合併症であることを物語るものであろう。しか し留置期間が何年を越えると，腎機能の障害が始まる のか，あるいは結石形成や尿路感染が，どの程度腎機 能障害の発生に関与しているか，などの具体的な点に ついては未だ明らかとされてはいないようである。そ こで今回，腎機能障害の指標としてはやや甘いが，血 清クレアチニン值 $2.0 \mathrm{mg} / \mathrm{dl}$ を越える迄の期間を, Kaplan-Meier 法を応用して計算したのだが，全体と しては 15 年を過ぎると $50 \%$ の患者に腎機能障害が始ま る成績であった。これを結石合併の有無に分けて計算 すると, 結石合併例では11年に対し, 結石の無い例で は16年と両者間に差を認めた。更に尿路感染症の腎機 能障害発生への影響も調べた。この場合長期カテーテ ル留置例での，尿路への細菌感染は必発であるので, 細菌尿の存在は必ずしも尿路感染症発症の指標之はな らない，そこで症候性尿路感染症の主症状である発熱 
を年 1 回以上繰り返した頻回発熱例と，それ以外の非 発熱例に分けて計算した。結果は前者は11年に対し， 後者は 17 年で $50 \%$ の患者の腎機能障害が始まってお り, 発熱を伴ら尿路感染症も, やはり腎機能へ悪影響 を与えている事実が認められた。 以上の結果より，上 部尿路への長期カテーテル留置は, 特に, 結石合併と 症候性尿路感染症の発症により, 腎機能障害が促進さ れることが改めて確認された，従って，止むなく上部 尿路に直接長期間カテーテルを留置する場合には，水 分の多量摂取などで, 結石発生や尿路感染を出来るだ け防止する配慮を払うことの重要性を強調して稿を終 わる。

\section{結 語}

各種疾患により 3 年以上長期間, 上部尿路に直接力 テーテルを留置している患者の腎機能の推移を調べた が，15年で約 $50 \%$ の腎機能障害が始まっていた。従っ て出来るだけ長期カテーテル留置は避けるべきと考え られた。 また結石合併例や頻回発熱例ではその数值が もっと短くなるので, カテーテル留置が不可避の場合 は, 結石発生や尿路感染症の発症を可及的に予防すべ きと考えられた。

\section{文献}

1) Milroy, M.D., Thompson, I.M., Depauw, A.P. and Ross, G. Jr.: - Permanent cutaneous ureterostomy : 18 years of experience. J. Urol., 120, 682-684, 1978.

2) Hirokawa, M., Iwasaki, A., Yamazaki, A., Asakura, S., Nozaki, A. and Yamagishi, T.:
Improved technique of cutaneous ureterostomy and results of permanent urinary diversion. Eur. Urol., 16, 125-123, 1989.

3) Feminella, J.G. Jr. and Lattimer, J.K.: A retrospective analysis of 70 cases of cutaneous ureterostomy. J. Urol., 106, 538-540, 1971.

4) Ohkawa, M., Sugata, T., Sawaki, M., Nakashima, T., Fuse, H. and Hisazumi, H.: Bacterial and crystal adherence to the surfaces of indwelling urethral catheters. J. Urol., 143, 717-721, 1990.

5）村上信乃, 藤田道夫, 田村欣一, 大谷かおる, 長谷 川範子：下部尿路手術後の留置カテーテル管理に ついて. 臨泌, 31，715-720, 1977.

6) Roberts, J.A., Fussell, E.N. and Kaack, M.B.: Bacterial adherence to urethral catheters. J. Urol., 144, 264-269, 1990.

7) Nickel, J.C., Grant, S.K. and Costerton, J.W.: Catheter-associated bacteriuria. An experimental study. Urology, 26, 369-375, 1985.

8）公文裕巳：カテーテル留置複雑性尿路感染症の病 態と治療学. 化学療法の領域, 6, 267-273, 1990.

9) Stickler, D., Dolman, J., Rolfe, S. and Chawla, J.: Activituof antiseptics against Escherichia coli growing as biofilms on silicone surfaces. Eur. J. Clin. Microbiol. Infect. Dis., 8, 974-978, 1989.

10）日本透析療法学会：表 451991 年末現在患者原疾 患. わが国の慢性透析療法の現況, 1991 年 12 月 31 日現在, p. 53, 1991.

（1993 年 3 月 1 日受理，特別掲載） 